\title{
A SUCCESSFUL SOLITARY CLIFF SWALLOW NEST
}

\author{
by Wayne Renaud, Rosetown
}

During June and July, 1968, a farmer repeatedly destroyed the nests of a colony of six or eight pairs of Cliff Swallows which were attempting to build beneath the eaves of a twostorey farm house one and one-half miles southeast of Valley Centre, Saskatchewan. One July 1, I noticed Cliff Swallows flying about nearly every building in Valley Centre; the next day I found first signs of construction of a nest under the large eaves of the unused Valley Centre railway sitation. I presume that this location was a last resort for the swallows for it presented several disadvantages: it was a painted structure; the 10-foot high eaves were unusually low for this species to nest under without the protection of water; and the only available nesting material was in a dugout in a pasture half a mile north of town. Since the July temperatures remained in the vicinity of 80 to 90 degrees, nest-building mus't have been a strenuous effort.

Solitary nesting in the highly colonial Cliff Swallow is uncommon but has been previously recorded. According to the Bent Life Histories series (U.S. Nat'l Mus. Series No. 179, 1942): "it is exceptional to find isolated nests far distant from others of this species." I was told by a neighbor that a single nest of this species had been built on their barn half a mile south of Valley Centre. Often, during the period of observation, flocks of Cliff Swallows were seen flying about buildings in town. These were thought to be from the same disturbed colony, wandering about the country like bands of winged gypsies.

By standing inside the station, I was able to obtain a good view of the activities at the nest site. On July 3 mud was placed in two piles along telephone wires which ran along a 6-by-6 supporting the eave. At first I suspected that two nests were going up side by side as the mud was placed at random along an 11-inch length of wire, Cliff Swallow nests usually being six or seven inches wide. I I requently saw a third swallow flying under the eaves and attempting to land near the nest, but only the one pair was involved in the completion of the nest.

On July 4 there was little activity at the nest and I found no evidence that mud had been brought. They were away most of the day, coming back only for brief periods of rest. I suspected that they were looking for a more favourable nesting location. They were back again the following day, bringing mud to the nest. In the evening of July 7 , I found the two piles of mud pellets joined, and additional pellets along the front wall. On July 6 and 7 the nest was rapidly taking shape, on one side a portion of the wall being built right to the roof. On the morning of the 7 th I found a broken egg beneath the nest but no eggs in the nest, as it was only partially built. I didn't get back until the 15 th on which date there was an unbroken egg on the ground. On the 18th there were two eggs in the nest. On the next day a third egg was laid in the nest. These three eggs hatched and the young left the nest in August.

The finished nest was a curiously built structure. The entrance was two and one-half inches wide and two inches high and was little more than a hole in the front of the mud chamber, with a decidedly more downward than outward slant. The swallows, perhaps in a hurry to complete the nest, had cut the entrance off short. The inner width of the mud compartment was about 10 inches. The distance from the entrance to the rear was about eight inches. I later found it to weigh about one and threequarter pounds, a little more than the one and one-half pounds average of five nests in my collection. 